\section{Europe attacks tactics that delay generic drugs}

The European Commission last week promised tougher scrutiny of drug industry deals that maximize profits on branded medicines by slowing consumers' access to cheap generic drugs.

It opened an investigation into Servier, a pharmaceutical company headquartered in Neuilly-sur-Seine, France, and several other drug manufacturers, over agreements that may have breached anti-trust laws.

Neelie Kroes, the European competition commissioner, also announced the final report of her department's 18-month inquiry into competition in the pharmaceutical sector (see http:// tinyurl.com/EUreport). The report says that 'company practices' are delaying the market entry of generic drugs, but notes that shortcomings in Europe's regulatory framework might be a factor too.

An industry trade body, the European Federation of Pharmaceutical Industries and Associations, approved of the reference to regulatory obstacles. It says that the findings show a "welcome shift away from the emotive language" of an interim report released last November.

\section{Obama names next head of US Geological Survey}

A California-based geophysicist is set to become the first woman to direct the US Geological Survey (USGS) in its 130-year history.

Marcia McNutt, now president and chief executive of the Monterey Bay Aquarium Research Institute (MBARI) in Moss Landing, expects her Senate confirmation hearing by September, following her nomination last week by President Barack Obama. The USGS has an annual budget of $\$ 1$ billion and 8,800 members of staff.

McNutt, an avid horsewoman who has run the MBARI since 1997, would also become the science adviser to the secretary of the interior.

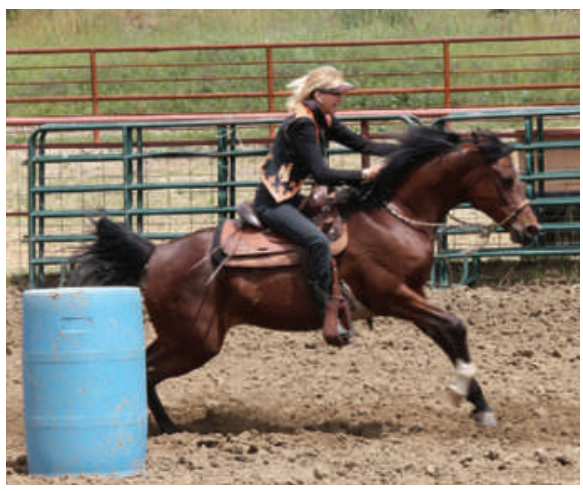

Marcia McNutt is set to take the reins at the USGS.

\title{
Mars Science Laboratory devours budgets
}

\begin{abstract}
A further budget overrun for NASA's Mars Science Laboratory rover (pictured), due to launch in 2011, could for the first time delay other missions in the agency's cashstrapped planetary-science division.

In a report due to be handed to Congress by the end of July, NASA will announce that the mission needs between $\$ 15$ million and \$115 million more than its estimated price

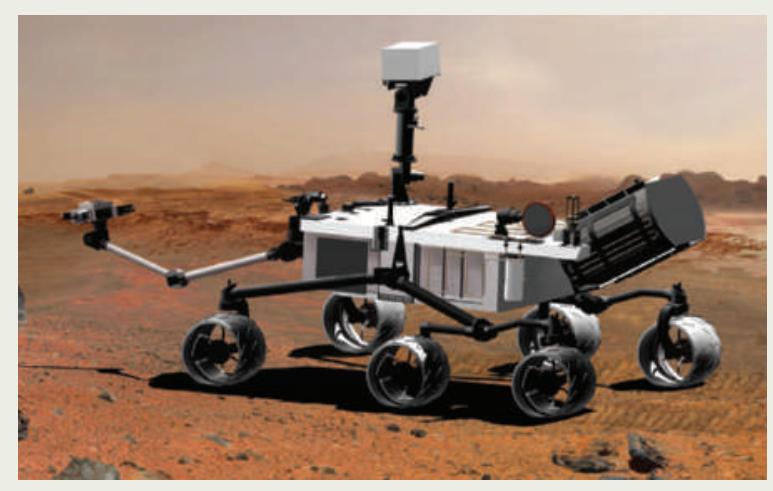
tag - which, at $\$ 2.28$ billion, is already $40 \%$ above an official $\$ 1.63$-billion estimate made in 2006

The agency has so far raided technology-development funds within the Mars programme, but if additional costs rise too much, it may have to delay two planned Moon missions. "The time for some tough decisions is here," said NASA science chief Ed Weiler, breaking the news to planetary scientists at an advisory-committee meeting on 9 July at NASA headquarters in Washington DC. Weiler also confirmed, as expected, that NASA would work in partnership with the European Space Agency on all future major Mars missions.

For a longer version of this story, see http://tinyurl.com/marscash
\end{abstract}

\section{El Niño arrives in the Pacific Ocean}

US climate scientists last week announced the arrival of El Niño, a cyclical rise in seasurface temperatures in the central and eastern Pacific Ocean. The event is known to influence fisheries and global weather patterns.

El Niños, which are associated with a weakening in the easterly trade wind, occur every two to five years and typically last for about a year. The current one is expected to continue developing over the next several months and to last through the winter, according to the National Oceanic and Atmospheric Administration in Washington DC.

Previous El Niños have seen more rainfall over the central tropical Pacific, drought in Indonesia and powerful winter storms in California as well as flooding and mudslides in Central and South America. The phenomenon has also been linked to less hurricane activity in the Atlantic Ocean and additional winter precipitation in the arid southwestern United States.

\section{German molecular biologist to head EMBO}

Maria Leptin was last week appointed the new head of the European Molecular Biology Organization (EMBO). She is only the fifth director in the 45-year history of the organization, which has more than 1,300 members.

Leptin, who works on cell shapes and immunity at the University of Cologne, Germany, says that she hopes EMBO will improve connections with India, China and the United States, and that it can influence governments on policy matters such as stem-cell research.

She will move to EMBO's base at the European Molecular Biology Laboratory in Heidelberg, Germany, in January next year.

For an interview with Maria Leptin,

see http://tinyurl.com/Leptininterview

\section{US renewable energy gets cash boost}

The Obama administration announced plans on 9 July to pump billions of dollars directly into the US renewable-energy market, providing a new avenue for funding that had dried up during the banking crisis.

The programme allows developers to receive cash payments, in lieu of existing tax subsidies, for wind, solar and other renewable-energy projects. Until now, such payments had tended to flow through banks, which provided upfront financing in exchange for tax credits. The new approach, sought by the renewable-energy industry and backed by Congress in its February stimulus bill, allows direct access to the subsidies.

The Department of Energy plans to begin accepting applications in August, and estimates that demand could exceed $\$ 3$ billion, enabling some $\$ 10$ billion to $\$ 14$ billion in projects.

\section{Correction}

The News Feature 'One gene, twenty years' (Nature 460, 164-169; 2009) incorrectly stated Robert Beall's current title. He is, in fact, president and chief executive of the Cystic Fibrosis Foundation. 